\title{
ANALISIS KADAR PROTEIN PRODUK SUSU CAIR YANG DIOLAH MELALUI PROSES PEMANASAN PADA SUHU YANG SANGAT TINGGI (ULTRA HIGH TEMPERATURE)
}

\author{
Gusti Ayu Eka Apriantini \\ Universitas Pendidikan Ganesha \\ Singaraja, Indonesia \\ e-mail: ekaapriantigs@gmail.com
}

\begin{abstract}
Abstrak
Penelitian ini bertujuan untuk mengetahui (1) kadar protein dari beberapa produk susu cair yang diolah melalui proses pemanasan pada suhu yang sangat tinggi (Ultra High Temperature), (2) kualitas produk susu cair tersebut berdasarkan proteinnya menurut persyaratan Standar Kesehatan Nasional atau SNI (Standar Nasional Indonesia). Subjek dalam penelitian ini adalah beberapa produk susu cair yang diolah melalui proses pemanasan pada suhu yang sangat tinggi (Ultra High Temperature) berkemasan $1.000 \mathrm{~mL}$. Sedangkan objek penelitian ini adalah kadar protein produk susu cair tersebut. Pengambilan data dilakukan dengan metode Kjeldahl yaitu penentuan \% $\mathrm{N}$ yang dikalikan dengan faktor penentu protein susu sebesar 6,38. Dari hasil analisis diperoleh kadar protein rata-rata produk susu cair berkemasan $1.000 \mathrm{~mL}$ bermerek $A$ adalah sebesar $8,99 \%$, untuk susu cair bermerek B sebesar $4,03 \%$, dan susu cair yang bermerek C 3,69\%. Perbedaan kadar protein ketiga susu cair tersebut disebabkan oleh beberapa faktor penting penyusun komposisi susu sapi, meliputi jenis ternak, waktu pemerahan, umur sapi, penyakit sapi, dan pakan ternak sapi. Jika dibandingkan dengan persyaratan SNI, ketiga produk susu cair tersebut sudah memenuhi syarat Standar Kesehatan Nasional sehingga aman dikonsumsi dan layak diproduksi.
\end{abstract}

Kata kunci: Kadar Protein, Susu Cair, Suhu

\begin{abstract}
This study aimed to determine (1) the protein content of some milk products that are processed through a heating process at a very high temperature (Ultra High Temperature), (2) the quality of the liquid milk products based on their protein according to the requirements of the National Health Standard or SNI (Standar Nasional Indonesia). The subjects in this study were several liquid milk products that were processed through heating process at a very high temperature (Ultra High Temperature) in 1,000 mL packages. While the object of this research is the protein content of the liquid milk products. Data were collected using the Kjeldahl method, namely the determination of\% $N$ multiplied by the determinant factor of milk protein by 6.38 . From the analysis, it was found that the average protein content of liquid milk with $1000 \mathrm{~mL}$ brand $A$ was $8.99 \%$, for liquid milk brand $B$ was $4.03 \%$, and liquid milk brand $C$ was $3.69 \%$. The difference in protein content of the three milk caused by several important factors in the composition of cow's milk, including the type of livestock, milking time, age of the cow, cow disease, and cow feed. When compared with the SNI requirements, the three liquid milk products have met the requirements of the National Health Standards so that they are safe for consumption and fit for production.
\end{abstract}

Keywords: Protein Content, Liquid Milk, Temperature 


\section{Pendahuluan}

Pesatnya perkembangan industri susu segar dengan teknologi tertentu mendorong pemerintah untuk memberikan perlindungan bagi semua produk susu cair yang beredar di pasaran. Berdasarkan sejumlah riset dari pakar gizi nasional, diketahui bahwa tidak mudah mendapatkan susu sesuai dengan definisi SNI. Apalagi masyarakat lebih akrab dengan produk susu olahan, baik bentuk cair maupun bentuk padat.

Susu disebut sebagai makanan yang hampir sempurna karena kandungan zat gizinya yang lengkap. Selain air, susu mengandung protein, karbohidrat, lemak, mineral, enzim-enzim, serta vitamin A, C, dan D dalam jumlah memadai. Manfaat susu ini merupakan hasil dari interaksi molekul-molekul yang terkandung di dalamnya (Astawan, 2005).

Menurut Standar Nasional Indonesia (SNI), susu segar itu merupakan cairan yang berasal dari ambing sapi sehat dan bersih yang diperoleh dari cara pemerahan yang benar serta kandungan alaminya tidak dikurangi atau ditambah suatu apapun dan belum mendapat perlakuan apapun.

Susu UHT adalah susu segar atau susu rekonstitusi atau susu rekombinasi yang disterilkan pada suhu tidak kurang dari $135^{\circ} \mathrm{C}$ selama 2 detik dan segera dikemas dalam kemasan steril. Pemanasan suhu tinggi dimaksudkan untuk membunuh bakteri sehingga mengakibatkan citarasa susu yang dihasilkan tidak terlalu bagus, akan tetapi kelebihan kandungan gizinya diformulasikan menyerupai susu segar dan susu formula bubuk. Kandungan lemak susu tidak kurang dari $3,25 \%$ dan kandungan padatan bubuk lemak tidak kurang dari $8,25 \%$. Waktu simpannya mencapai 6 bulan sampai setahun dalam suhu ruangan.

Komposisi susu dapat sangat beragam tergantung pada beberapa faktor, antara lain jenis ternak, waktu pemerahan, pakan ternak, umursapi, dan lain-lain. Penetapan kadar protein dalam bahan makanan umumnya dilakukan berdasarkan penetapan secara empiris, yaitu penentuan kandungan nitrogen $(\mathrm{N})$ yang ada dalam bahan makanan. Dasar perhitungan penentuan protein menurut Kjeldhal ini adalah hasil penelitian dan pengamatan yang menyatakan bahwa umumnya protein alamiah mengandung unsur $\mathrm{N}$ rata-rata 165 (dalam protein mumi). Untuk senyawa-senyawa protein tertentu yang telah diketahui kadar unsur $\mathrm{N}$ nya, maka angka yang lebih tepat dapat dipakai.

Apabila jumlah unsur $\mathrm{N}$ dalam bahan telah diketahui, maka jumlah protein dapat dihitung dengan menggunakan persamaan 1.

$$
\text { Kadar }=-X-100149
$$

Keterangan:

$\mathrm{Vj}=$ Volume asam sufat untuk titrasi cuplikan $(\mathrm{mL})$.

V2 $=$ Volume asam sulfat untuk titrasi blanko $(\mathrm{mL})$.

$\mathrm{N}=$ Normalitas asam sulfat.

$\mathrm{Bu}=$ Bobot cuplikan yang ditimbang (gram.).

$\mathrm{F}=$ Faktor dari cuplikan

Faktor cuplikan dari beberapa bahan pangan dapat dilihat pada Tabel 3 dibawah ini.

Tabel 1. Faktor Perkalian f Beberapa Bahan Pangan.

\begin{tabular}{lc}
\hline \multicolumn{1}{c}{ Macam Bahan } & Faktor Perkalian \\
\hline Bir, sirup, biji-bijian, ragi & 6,25 \\
Buah, teh, anggur, malt & 6,25 \\
Makanan ternak & 6,25 \\
Beras & 5,95 \\
Roti, gandum, makaroni, mie & 5,7 \\
Kacang tanah & 5,46 \\
Kedelai & 5,75 \\
Kenari & 5,18 \\
Susu & 6,38 \\
Gelatin & 5,55 \\
\hline
\end{tabular}

(Sudarmadji,dkk, 2003). 
Industri pengolahan susu dengan menggunakan teknologi tertentu seperti UHT dan Pasteurisasi diharapkan mampu memenuhi Standar Kesehatan Nasinal. Setidaknya dengan proses pengolahan susu segar UHT diharapkan dapa meminimalisasi kerusakan gizi dan mutu sensoris dari susu cair tersebut.

Padahal susu bubuk itu sendiri juga berasal dari susu segar atau rekombinasi dengan zat lain seperti lemak dan protein yang dikeringkan. Namun proses pengolahan susu bubuk yang umumnya melalui pengeringan dengan waktu yang cukup lama sangat berpengaruh terhadap mutu sensoris dan gizi terutama vitamin dan protein itu sendiri. Menurut Astawan, kerusakan protein bisa berupa terbentuknya pigmen coklat (melonodin) akibat reaksi Maillard. Reaksi ini biasanya terlihat pada pencoklatan non-enzimatik yang terjadi antara gula dan protein susu akibat proses pemanasan yang berlangsung cukup lama. Pemanasan seperti ini dapat menurunkan daya cerna protein. Reaksi Maillard seringkali dapat menghasilkan akrilamida pada saat pemanasan asam amino yang berlangsung pada suhu $150^{\circ} \mathrm{C}-260^{\circ} \mathrm{C}$, kira-kira suhu pemanasan saat memasak (Ismunandar, 2003). Pemanasan susu dengan suhu tinggi dalam waktu lama juga dapat menyebabkan terjadinya rasemisasi asam-asam amino, yaitu perubahan konfigurasi asam amino dari bentuk $L$ ke bentuk $D$. Padahal tubuh manusia hanya dapat menggunakan asam amino dalam bentuk L. Oleh karena itu, semua orang kembali berlomba-lomba untuk mengkonsumsi susu secara alamiah atau susu segar. Hanya sayangnya susu segar yang diperoleh dari pemerahan sapi tidak tahan lama. Rata-rata dalam waktu enam jam kondisi susu akan rusak karena kontaminasi dengan udara yang memudahkan munculnya bakteri pembusuk (Sri Rahayu, 2005).

\section{Metode}

Penelitian ini merupakan penelitian eksperimen, untuk menentukan kadar protein beberapa produk susu cair yang diolah melalui proses pemanasan dengan suhu yang sangat tinggi \{Ultra High Temperature) menggunakan metode semi- mikro Kjeldahl.

Subjek dalam penelitian ini adalah beberapa produk susu cair yang diolah melalui pemanasan pada suhu yang sangat tinggi (Ultra High Temperature) berkemasan $1.000 \mathrm{~mL}$. Objek penelitian adalah kadar protein beberapa produk susu cair yang diolah melalui proses pemanasan pada suhu yang sangat tinggi (Ultra High Temperature).

Dalam tahap analisis sampel maka dapat didiskripsikan prosedur kerja dalam penetapan kadar protein menggunakan metode semi-mikro Kjedhal adalah sebagai berikut. a) Sampel setara dengan 0,03 - 0,04 gram Nitrogen ditimbang dengan seksama dan dimasukkan ke dalam labu Kjedhal, b) Ditambahkan 10 gram selenium dan $20 \mathrm{~mL}$ asam sulfat pekat, c) Campuran tersebut didegesti pada suhu tinggi sampai cairan jernih dan kemudian didinginkan, d) Campuran dipindahkan ke dalam labu destilasi dan dibilas dengan sejumlah air, e) Larutan $\mathrm{NaOH} 50 \%$ b/v berlebih ditambahkan pada campuran dan segera didestilasi, f) Destilat sebanyak $200 \mathrm{~mL}$ ditampung dalam labu erlenmeyer yang telah berisi $50 \mathrm{~mL}$ larutan asam borat $4 \% \mathrm{~b} / \mathrm{v}$ dan 4 tetes indikator campuran, g) Larutan tersebut dititrasi dengan asam sulfat $0,1 \mathrm{~N}$ sampai warna hijau berubah menjadi biru-violet, h) Hasil titrasi dicatat pada LCP (yang dicatat adalah volume dari titran yang digunakan), i) Blanko juga diberi perlakuan sama seperti sampel yang dianalisis.

Penentuan kadar protein pada beberapa produk susu cair yang diolah melalui proses pemanasan pada suhu yang sangat tinggi (Ultra High Temperature) digunakan analisis data secara statistik diskriptif, yaitu melalui suatu pemaparan data yang penyampaian datanya menggunakan data pengujian berupa tabel-tabel pengujian. Penentuan kadar protein pada beberapa produk susu cair yang diolah melalui proses pemanasan pada suhu yang sangat tinggi (Ultra High Temperature) digunakan analisis data secara statistik diskriptif, yaitu melalui suatu pemaparan data yang penyampaian datanya menggunakan data pengujian berupa tabeltabel pengujian.

\section{Hasil dan Pembahasan}

Data hasil titrasi contoh dan blanko dengan menggunakan asam sulfat untuk menentukan \%N dalam penentuan kadar protein beberapa produk susu cair yang diolah melalui proses pemanasan pada suhu yang sangat tinggi (Ultra High Temperature) disajikan pada Tabel berikut. 
Tabel 1. Data Hasil Analisis Susu UHT A (143/M/1V/05)

\begin{tabular}{cccccc}
\hline $\begin{array}{c}\text { Nama } \\
\text { Zat Uji }\end{array}$ & $\begin{array}{c}\text { Nomor } \\
\text { Pengujian }\end{array}$ & $\begin{array}{c}\text { Wadah+Zat } \\
\text { (gram) }\end{array}$ & $\begin{array}{c}\text { Wadah+Sisa } \\
\text { (gram) }\end{array}$ & $\begin{array}{c}\text { Faktor } \\
\text { Pengenceran }\end{array}$ & $\begin{array}{c}\text { Titran } \\
\text { (mL) }\end{array}$ \\
\hline Sampel A & $1-1$ & 9,4820 & 6,6348 & $10 \mathrm{kali}$ & 2,15 \\
Sampel A & I-2 & 5,4815 & 3,3845 & $10 \mathrm{kali}$ & 1,8 \\
Sampel A & $11-1$ & 5,8765 & 3.7925 & $10 \mathrm{kali}$ & 2,1 \\
Sampel A & II-2 & 8,2365 & 5,8020 & $10 \mathrm{kali}$ & 1,9 \\
Sampel A & $111-1$ & 6,8765 & 4.8543 & $10 \mathrm{kali}$ & 2,0 \\
Sampel A & $111-2$ & 5,5815 & 3,4867 & $10 \mathrm{kali}$ & 1,85 \\
Sampel A & IV-1 & 5,2398 & 3,1345 & $10 \mathrm{kali}$ & 1,8 \\
Sampel A & IV-2 & 5.7546 & 3,7401 & 10 kali & 1,83 \\
\hline
\end{tabular}

Tabel 2. Data Hasil Analisis Susu UHT B (142/M/IV/05)

\begin{tabular}{cccccc}
\hline $\begin{array}{c}\text { Nama } \\
\text { Zat Uji }\end{array}$ & $\begin{array}{c}\text { Nomor } \\
\text { Pengujian }\end{array}$ & $\begin{array}{c}\text { Wadah+Zat } \\
(\mathbf{g r a m})\end{array}$ & $\begin{array}{c}\text { Wadah+Sisa } \\
(\mathbf{g r a m})\end{array}$ & $\begin{array}{c}\text { Faktor } \\
\text { Pengenceran }\end{array}$ & $\begin{array}{c}\text { Titran } \\
(\mathbf{m L})\end{array}$ \\
\hline Sampel B & $1-1$ & 6,4328 & 4,1298 & $10 \mathrm{kali}$ & 1,1 \\
Sampel B & I-2 & 4,5989 & 2,1003 & $10 \mathrm{kali}$ & 1,15 \\
Sampel B & $11-1$ & 5,6725 & 3,4513 & $10 \mathrm{kali}$ & 1,1 \\
Sampel B & II-2 & 8.4320 & 5,4101 & $10 \mathrm{kali}$ & 1,2 \\
Sampel B & $111-1$ & 5,8788 & 3,2767 & $10 \mathrm{kali}$ & 1,17 \\
Sampel B & III-2 & 5,4678 & 3,1298 & $10 \mathrm{kali}$ & 1,1 \\
Sampel B & IV-1 & 6,1324 & 4,1143 & $10 \mathrm{kali}$ & 1,23 \\
Sampel B & IV-2 & 5,9812 & 3,4209 & 10 kali & 1,2 \\
\hline
\end{tabular}

Tabel 3. Data Hasil Analisis Susu UHT C (141/M/IV/05)

\begin{tabular}{cccccc}
\hline $\begin{array}{c}\text { Nama } \\
\text { Zat Uji }\end{array}$ & $\begin{array}{c}\text { Nomor } \\
\text { Pengujian }\end{array}$ & $\begin{array}{c}\text { Wadah+Zat } \\
\text { (gram) }\end{array}$ & $\begin{array}{c}\text { Wadah+Sisa } \\
\text { (gram) }\end{array}$ & $\begin{array}{c}\text { Faktor } \\
\text { Pengenceran }\end{array}$ & $\begin{array}{c}\text { Titran } \\
(\mathbf{m L})\end{array}$ \\
\hline Sampel C & $1-1$ & 10,8988 & 8,3126 & $10 \mathrm{kali}$ & 1,1 \\
Sampel C & I-2 & 6,2487 & 4,1465 & $10 \mathrm{kali}$ & 1,15 \\
Sampel C & $11-1$ & 5,4389 & 3,1398 & $10 \mathrm{kali}$ & 1,1 \\
Sampel C & II-2 & 9,5477 & 7,1747 & $10 \mathrm{kali}$ & 1,2 \\
Sampel C & $111-1$ & 9,6576 & 7,2590 & $10 \mathrm{kali}$ & 1,15 \\
Sampel C & III-2 & 6,4657 & 4,2647 & $10 \mathrm{kali}$ & 1,05 \\
Sampel C & IV-1 & 5.8675 & 3,1098 & 10 kali & 0,9 \\
Sampel C & IV-2 & 6,3466 & 4,1454 & 10 kali & 1,0 \\
\hline
\end{tabular}

Tabel 4. Data Hasil Analisis Blanko

\begin{tabular}{cc}
\hline Jenis Pengujian & Titran $(\mathbf{m L})$ \\
\hline Blanko & 0,1 \\
\hline
\end{tabular}

Untuk analisis sampel dan blanko digunakan penitrasi berupa asam sulfat $0,1 \mathrm{~N}$ dengan harga normalitas pembakuan sebesar 0,0970.

Dari hasil perhitungan diperoleh kadar protein rata-rata protein beberapa produk susu cair yang diolah melalui proses pemanasan pada suhu yang sangat tinggi (Ultra High Temperature) adalah sebagai berikut: Susu bermerek $A(143 / \mathrm{M} / \mathrm{IV} / 05)=8,99 \%$, Susu bermerek B $(142 / \mathrm{M} / \mathrm{IV} / 05)=4,03 \%$, Susu bermerek C $(141 / \mathrm{M} / \mathrm{IV} / 05)=3,69 \%$

Data ini menunjukkan bahwa susu cair yang bermerek $A$ lebih baik dikonsumsi dibandingkan susu cair yang bermerek B dan C. Begitu juga susu cair yang bermerek B lebih baik dikonsumsi dibandingkan yang bermerek $\mathrm{C}$, bila ditinjau dari kadar proteinnya. Ketiga produk susu cair tersebut sudah memenuhi Standar Kesehatan Nasional atau SNI sehingga layak produksi, aman dikonsumsi masyarakat luas, dan baik untuk kesehatan.

Jika dilihat dari komposisi rata-rata susu sapi maka dapat diketahui bahwa kadar protein rata-rata ketiga susu cair yang diolah melalui proses pemanasan pada suhu yang sangat tinggi (Ultra High Temperature) sudah berada diatas rata-rata komposisi susu sapi. Ini menunjukan bahwa dalam pengolahan susu segar yang menggunakan pemanasan pada suhu 
yang sangat tinggi (Ultra High Temperature) tidak terjadi kerusakan protein. Hal ini membuktikan bahwa tidak terjadi reaksi Maillard dalam proses pemanasan pada suhu yang sangat tinggi (Ultra High Temperature) sehingga tidak akan terbentuk karamelisasi maupun berlangsungnya pembentukan warna coklat melalui reaksi Amadori dan kondensasi aldol membentuk melanoidin.

Proses pemanasan pada susu UHT tidak berpengaruh terhadap mutu sensoris dan gizi susu cair sehingga tidak terlihat adanya pembentukan pigmen coklat pada susu UHT. Dengan demikian tidak akan terjadi reaksi non-enzimatik antara gula dan protein susu sehingga tidak terjadi penurunan daya cerna protein tubuh. Ini disebabkan karena untuk susu UHT, pengolahannya menggunakan pemanasan pada suhu tinggi dalam waktu yang relatif singkat yaitu dalam waktu 2-5 detik. Proses pemanasan seperti ini selain dapat membunuh seluruh mikroorganisme (bakteri pembusuk maupun patogen) dan spora (jamur) juga untuk mencegah kerusakan nilai gizi (nutrisi mikro, seperti vitamin dan mineral). Bahkan dengan proses UHT, warna, aroma dan rasa relatif tidak berubah dari aslinya sebagai susu segar (Ismunandar, 2003).

Teknologi dengan sistem robot pada pengolahan susu UHT siap memanaskan suhu selama empat detik dengan suhu $140^{\circ} \mathrm{C}$. Setelah itu susu yang diproses dikemas dalam kemasan aseptik yakni menggunakan kemasan multilapis terdiri dari kertas, plastik, polyethylene dan aluminium foil agar kedap udara dan cahaya. Kemasan tersebut mampu melindungi kualitas susu cair dari pengaruh sinar ultraviolet hingga 10 bulan. Dengan begitu susu cair UHT tanpa bahan pengawet ini bisa bertahan lama setidaknya sampai enam bulan, dengan catatan kemasannya masih utuh dan tidak cacat.

Dalam analisis susu cair UHT digunakannya metode Kjeldhal dalam analisisnya karena disebabkan oleh penentuan protein berdasarkan jumlah nitrogen menunjukkan protein kasar, karena selain protein juga terikut senyawa $\mathrm{N}$ bukan protein, misalnya urea, asam nukleat, ammonia, nitrat, nitrit, asam amina, amida, purin dan pirimidin. Selain itu dengan penggunaan selenium dalam jumlah kecil atau sedikit yaitu kurang dari 0,25 gram pada tahap destruksi akan mencegah hilangnya nitrogen meskipun selenium sangat cepat teroksidasi. Hal ini karena selenium dapat menaikkan titik didih dan mudah mengadakan perubahan dari valensi tinggi ke valensi rendah atau sebaliknya.

Pada tahap destilasi pecahnya ammonium sulfat menjad ammonia oleh penambahan $\mathrm{NaOH}$ pada suhu pemanasan akan ditampung oleh larutan asam borat $4 \%$ yang mana dalam prosesnya ditambahkan batu didih untuk mencegah muncrat dan tumpahnya larutan destilasi sehingga akan dapat berlangsung lebih cepat dan sempurna.

Penggunaan asam borat sebagai larutan asam standar memungkinkan pada tahap titrasi akan diketahuinya berapa banyaknya asam borat yang bereaksi dengan ammonia melalui asam sulfat dan indikator campuran. Selisih jumlah titrasi sampel dan blanko merupakan jumlah ekuivalen nitrogen. Setelah diperoleh \%N selanjutnya akan dihitung kadar proteinnya dengan mengalikan suatu faktor dan hasilnya akan segera dibandingkan dengan standar SNI. Dalam titrasi digunakannya asam sulfat karena dalam tahapan ini yang diharapkan adalah terjadinya reaksi asam dan basa (redoks).

\section{Simpulan dan Saran}

Dari hasil penelitian yang telah dilakukan, maka dapat disimpulkan bahwa: a) Kadar protein rata-rata masing-masing susu cair yang diolah melalui proses pemanasan pada suhu yang sangat tinggi (Ultra High Temperature) pada beberapa produk susu cair yang berbeda merek adalah sebagai berikut: Kadar protein rata-rata susu cair bermerek $A(143 / \mathrm{M} / \mathrm{IV} / 05)=$ $8,99 \%$, Kadar protein rata-rata susu cair bermerek B $(142 / \mathrm{M} / \mathrm{IV} / 05)=4,03 \%$, Kadar protein, rata-rata susu cair bermerek C $(141 / \mathrm{M} / \mathrm{IV} / 05)=3,69 \%$; b) Kadar protein dari beberapa produk susu cair yang diolah melalui proses pemanasan pada suhu yang sangat tinggi (Ultra High Temperature) memenuhi persyaratan Standar Kesehatan Nasional atau SNI (Standar Nasional Indonesia) sehingga layak produksi dan konsumsi.

Berdasarkan pada hasil pembahasan, maka dapat penulis sarankan agar sebaiknya kita kembali mengkonsumsi susu secara alamiah atau susu segar seperti susu segar cair UHT karena kandungan gizinya yang sangat tinggi dan kemasannya yang lebih higienis. 


\section{Daftar Pustaka}

Andarwulan. 2005. " Susu Segar dan Susu Cair Apa Bedanya ?". www, Google, com. Maspada online/28 Februari 05/09: $26: 40$.

Anonim. 1999. Metabolisme Asam Amino. Jakarta : Gramedia.

Astawan. 2005. "Lebih Baik Mengonsumsi Susu Segar”, www, Google. com./16 Juli 05/09 : 26 : 55.

Astawan. 2005. "Proses UHT : Upaya Penyelamatan Gizi pada Susu." www. Kimia Indonesia, com./ Waspada online/Mei 05/10: 40.

Buckle. 1985. Ilmu Pangan. Jakarta : Gramedia.

Buckle. 1987. Food Science. Australia : AAUCS.

BBPOM. 2002. Metode Analisis. Jakarta : PPOMN.

David S Page. 1997. Prinsip-Prinsip Biokimia. Surabaya : Erlangga.

Departemen Agama RI. 2003. Makanan Sehat dan Halal. Jakarta : Balai Pustaka.

Girindra. 1986. Biokimia I. Jakarta : Gramedia.

Ismadi. 1993. Biokimia Suatu Pendekatan Berorientasi Kasus. Yogyakarta : UGM press.

Ismunandar. 2003. "Chem-is-try. 01.” www, Yahoo, com /webmaster@ Chem-is-try, org/02 Juni 05/08: $55: 40$.

Ismunandar. 2003, 3 Januari. “ Pembentukan Karsinogen Dalam Makanan.” Kompas.

Muchji. M. 1980. Teknologi Pengawetan Pangan, ed 3, Jakarta : Ul-press.

Soeharto. 1987. IImu Gizi Komparatif, ed 1. Yogyakarta : BFFS.

Sardjoko. 1991. Bioteknologi. Jakarta : Gramedia.

Senior. 2005. "Pasteurisasi.” www. Google, com./ 28 Februari 05/ 12 : 26 : 45.

Siti, dkk. 2001. Penuntun Belajar Biokimia. Singaraja : IKIP N Singaraja.

Sudarmadji,dkk. 2003. Analisa Bahan Makanan dan Pertanian. Yogyakarta : Liberty.

Wisnu. M. 2005. Nitrisionis dan Teknologi Susu. Yogyakarta : UGM. 